EESTI NSV TEADUSTE AKADEEMIA TOIMETISED, 27. KOIDE GEOLOOGIA, 1978, NR. 3

ИЗВЕСТИЯ АКАДЕМИИ НАУК ЭСТОНСКОИ ССР. ТОМ 27

ГЕОЛОГИЯ. 1978, № 3

\title{
ON THE OLDEST KNOWN TELEOSTOME FISH ANDREOLEPIS HEDEI GROSS (LUDLOW OF GOTLAND), AND THE SYSTEMATIC POSITION OF THE LOPHOSTEIDS
}

Andreolepis hedei was described by W. Gross (1968) on the basis of some scales found by A. Martinsson in the Hemse limestone, the Middle Ludlow of Gotland. In 1970 and 1971, the present writer, and some years later T. Ørvig and C. Pleijel collected new material, containing determinable dermal bones. On the basis of this material, further remarks can be made on the systematic position of $A$. hedei. The writer wishes to express his thanks to Prof. T. Ørvig for the possibility to describe the specimens of the Naturhistoriska Riksmuseet, Stockholm, and for valuable discussions. The macrophotographs have been made by U. Samuelsson, the scanning electron microscope photographs by Miss Weber and the drawings by the writer.

Geological occurrence. The remains of $A$. hedei have been prepared by acetic acid digestion of marly limestone from the locality called Gogs 1 (3.6 km SSE of Alskog church, southeastern part of Gotland, near Lau). According to A. Martinsson $(1962,1966)$, the age of this locality is the Middle Ludlow or Uppermost Lower Ludlow and could be the same as that of the «Colonus» shales of Scania.

The vertebrate fauna at Gogs has been listed as follows (Gross, 1968; Janvier, 1971): Thelodus parvidens Ag., T. cf. schmidti, ?Apalolepis sp., Thelodonti gen. et sp. indet., Phlebolepis elegans Pander, Archegonaspis (Lauaspis) sp., Cyathaspida gen. et sp. indet., Tremataspis sp., Nostolepis striata Pander, Gomphonchus sandelensis (Pander), G. hoppei (Gross), Andreolepis hedei Gross.

The assumption that Lophosteus sp. was present at Gogs (Janvier, 1971) was based on some detached scales which are referred to $A$. hedei now.

Description. The most determinable bone of $A$. hedei hitherto found is a part of the exoskeletal shoulder girdle, more precisely of the cleithrum of the right side of the fish (Fig. 1, $A-C$; Plate I, Figs 1-4). This bone presents a vertical, lateral part (v. p.) and a horizontal, ventral part (h. p.), suspending at an angle of about $110^{\circ}$. Its orientation is indicated by the ornamentation which consists of oval tubercles tapering backward and fusing with each other near the limit between the vertical and the horizontal parts (1. e). In the posterior depressed part (d. p.) of this bone and near the edge in question, the tubercles become leaf-shaped and are, in their turn, ornamented with faint ridges. In this region, also, the vertical part of the bone bends in a medial direction whereas the edge expands laterally to form a prominent lamina. The horizontal part of the bone is gently depressed in its middle region, and its medial limit seems to be brokẹn off. 


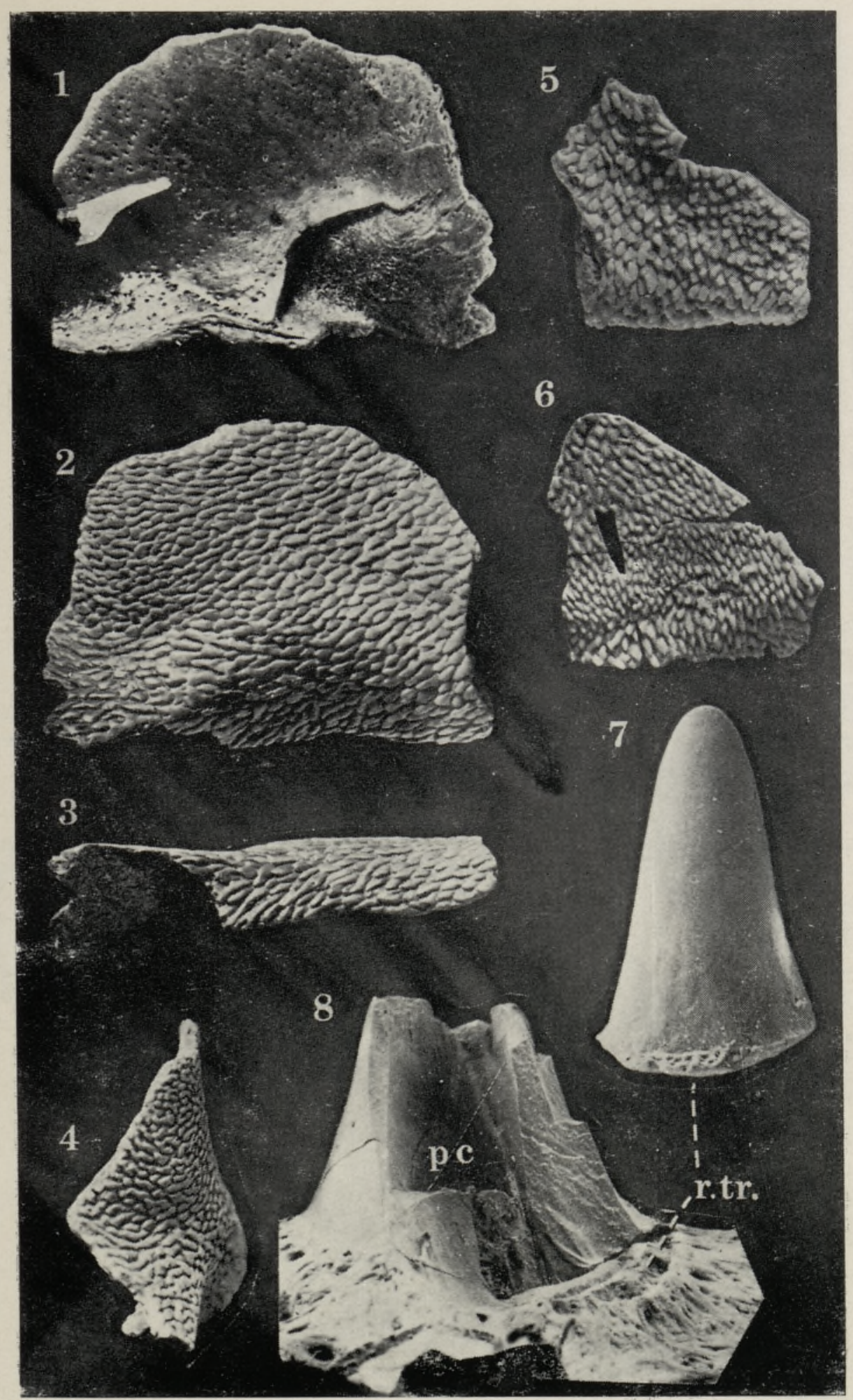

Plate I. Andreolepis hedei Gross, Middle Ludlow of Gotland (Sweden).

Figs 1-4. Fragment of the cleithrum of the right side in medial (1), lateral (2), ventral (3) and posterior (4) view; $\times 5$. Fig. 5. Fragment of the anterior part of a cleithrum of the right side in lateral view; $\times 5$. Fig. 6 . Fragment of dermal bone, presumably belonging to the exoskeletal shoulder girdle; $\times 5$. Fig. 7 . Detached tooth of the main tooth-rows; $\times 25$. Fig. 8 . Broken tooth attached on a tooth plate and showing traces of resorption (r. tr.) and the wide pulp cavity (p. c.); $\times 150$. (Figs $1-6-$ RM, Stockholm, Figs $7-8-M N H N$, Paris). 


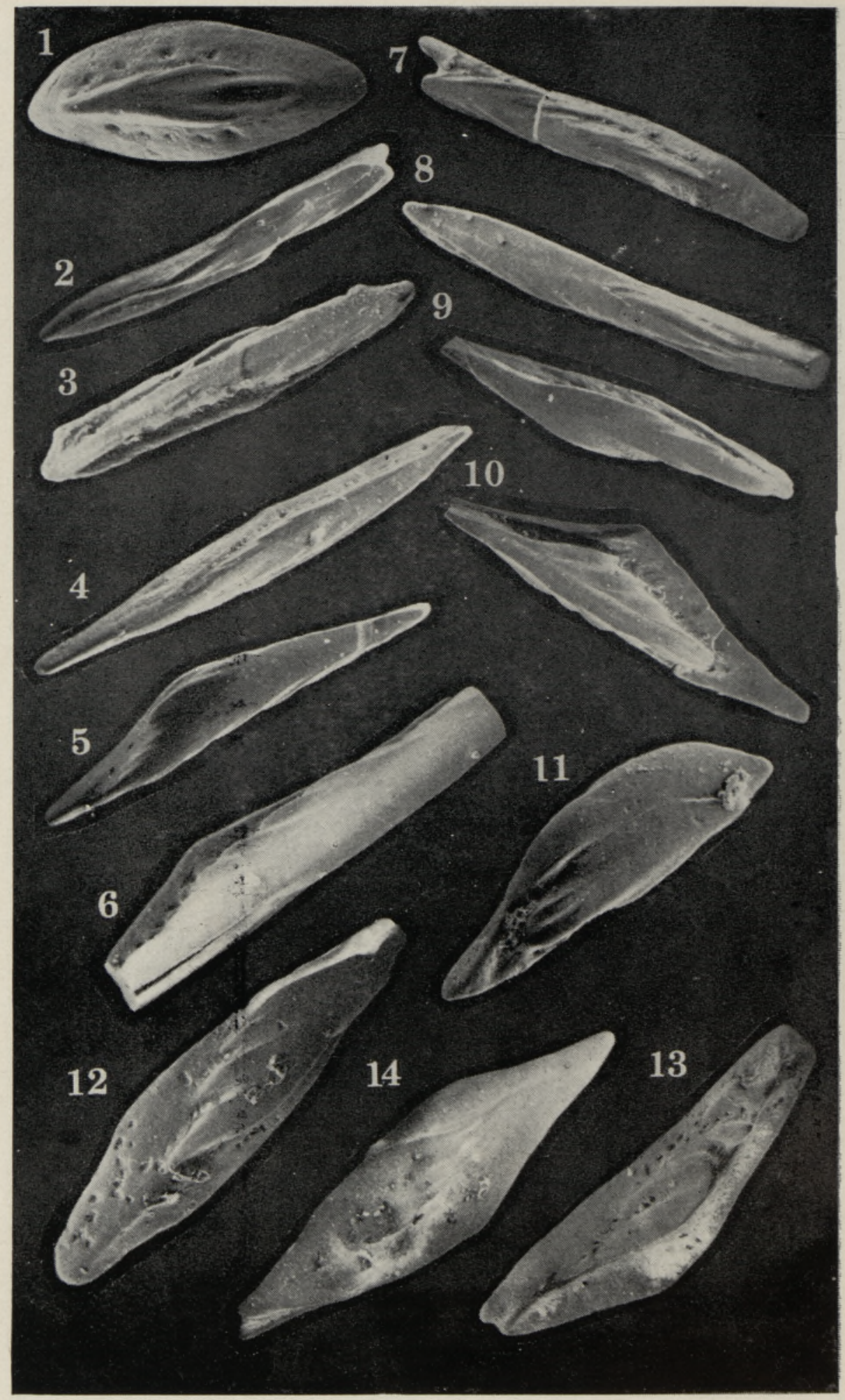

Plate II. Andreolepis hedei Gross, Middle Ludlow of Gotland (Sweden).

Fig. 1. Detached ventral scale; $\times 50$. Figs $2-10$. Detached «pseudofulcral» scales, presumably covering the edge of the caudal lobe; $\times 50$. Figs $11-113$. Detached scales from the caudal lobe; $\times 50$. Fig. 14. Detached scale from the right flank; $\times 35$. (Figs $1-14-$ MNHN, Paris). 


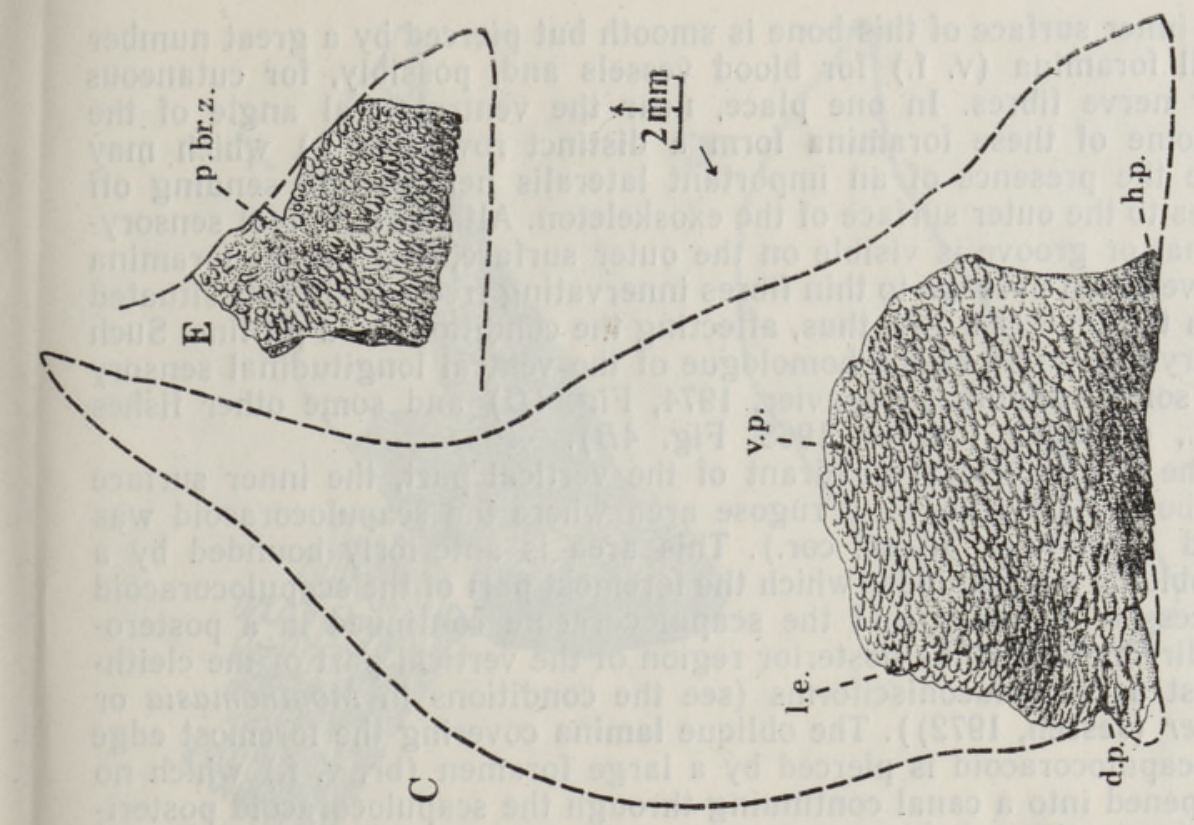

늘은은

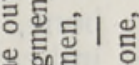
西的

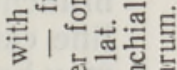
w必 产它娄 -1. प्र०ण

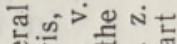
四吉落

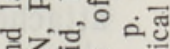

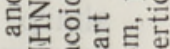
¿ 늘 흘

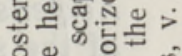

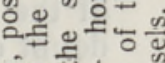

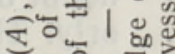
क० 중 홍 西藏的

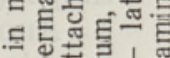
E

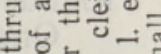
응 政 些

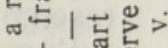
“1 1 呵

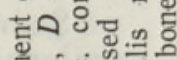

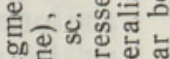
o. 㱏 누을 1 i.

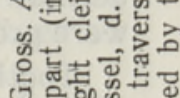

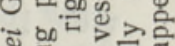
ชี.

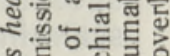
绳要

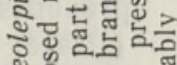

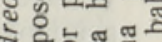

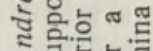

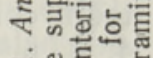
证宁异眾。 
The inner surface of this bone is smooth but pierced by a great number of small foramina (v. f.) for blood vessels and, possibly, for cutaneous sensory nerve fibres. In one place, near the ventrolateral angle of the bone, some of these foramina form a distinct row (lat. f.) which may indicate the presence of an important lateralis nerve trunk sending off branches to the outer surface of the exoskeleton. Although no real sensoryline canal or groove is visible on the outer surface, this row of foramina may have given passage to thin fibres innervating free neuromasts situated between the tubercles and, thus, affecting the conditions of a pit-line. Such a sensory-line could be the homologue of the ventral longitudinal sensory line of some agnathans (Janvier, 1974, Fig. 1D) and some other fishes as, e. g., dipnoans (Jarvik, 1968, Fig. 4B).

In the posteroventral quadrant of the vertical part, the inner surface of this bone clearly shows a rugose area where the scapulocoracoid was attached (Fig. 1, A, ar. sc. cor.). This area is anteriorly bounded by a sharp, oblique lamina under which the foremost part of the scapulocoracoid was recessed. It seems that the scapulocoracoid continued in a posterodorsal direction onto the posterior region of the vertical part of the cleithrum, just as in palaeonisciforms (see the conditions in Moythomasia or Acipenser (Jessen, 1972)). The oblique lamina covering the foremost edge of the scapulocoracoid is pierced by a large foramen (br. v. f.) which no doubt opened into a canal continuing through the scapulocoracoid posteriorly. This canal, probably for a vessel, may correspond to the foremost foramen of the scapulocoracoid encountered in several recent and fossil actinopterygians, e. g., Moythomasia, Palaeoniscus, Birgeria, Salmo and Elops (Jessen, 1972, p. 70).

Another, thinner bone fragment (Plate I, Fig. 6) may pertain to the anterior part of the cleithrum. It presents two kinds of tubercles: flat, rounded and elongated, tapering ones.

One more bone fragment (Fig. 1, E; Plate I, Fig. 5; Janvier, 1971, Fig. 2) may come from the anterior or anteroventral region of the vertical part of the cleithrum. It possesses an oblique anterolateral edge and a depressed field covered with smaller, rounded or triangular tubercles which resemble the ornamentation of the postbranchial lamina in some primitive actinopterygians.

Some lesser and very thin bone fragments of an indeterminate position are ornamented with elongated tubercles or even ridges of the same type as in many palaeonisciforms (Fig. 1, D). We may consider them as belonging to the exoskeleton of the head.

A spine-shaped dermal bone having the same ornamentation as the dermal bones mentioned above is very suggestive of the «stachelförmige» dermal bones of Lophosteus superbus (Gross, 1969, 1971). These bones were probably situated in front of the fins.

Tooth-bearing plates have been figured by the present writer (Janvier, 1971, Fig. 3, $a$, b; Fig. 4, $A$ in the present paper). Unfortunately, the specimens were partially crushed during their introduction into the scanning electron microscope, and the photograph in Plate I, Fig. 8 represents only a small part of the largest specimen. Larger detached teeth (Plate I, Fig. 7), probably belonging to the main tooth row, show resorption traces (r. tr.) near their base, as in L. superbus. Most of the teeth collected are strongly curved and possess a large pulp cavity (Fig. $4, B$, p. c.). The histological similarity between the teeth of $A$. hedei and those of L. superbus (see Gross, 1971) makes a detailed description of the thin section figured here (Fig. $4, B$ ) useless.

Most of the scales belong to the morphological types described by 

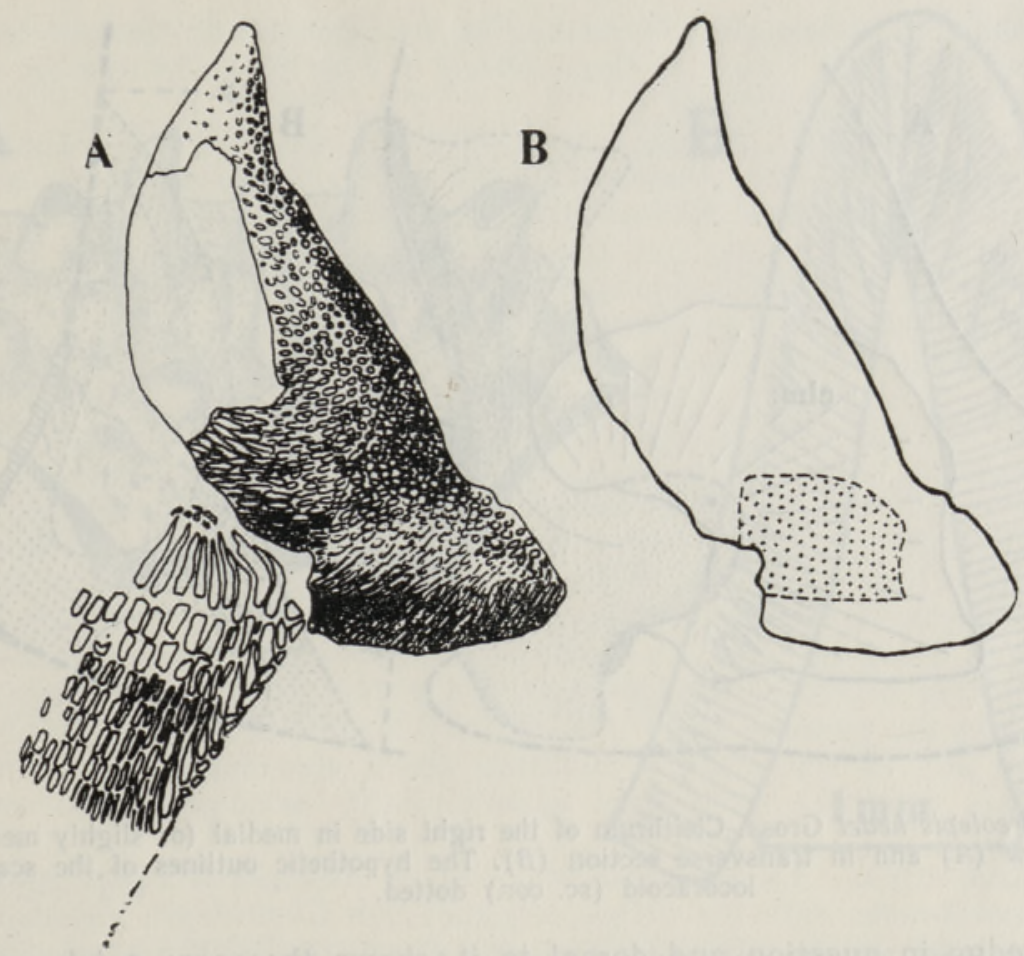

Fig. 2. Cheirolepis canadensis (Whiteaves). A-Cleithrum of the right side in dorsolateral view (from Lehman, 1947), B - Presumed position (dotted) of the part of the cleithrum compared with that of A. hedei.

W. Gross (1968), except some very elongated, almost rod-like ones (Plate II, Figs 1-10; Janvier, 1971, Fig. 4, $d, e$ ), which no doubt belong to the squamation of the caudal lobe.

Comparisons. When describing the scales of $A$. hedei, W. Gross (1968) compared them with those of some other Middle Palaeozoic fishes. He provisionally concluded that the scales of $A$. hedei, although having no enamel and being somewhat reminiscent of those of the acanthodian fish Nostolepis, in their histology, were very similar in shape to those of the Middle and Lower Devonian genus Orvikuina (Gross, 1953; Schultze, 1968; Hamdi, Janvier, in press). Comparisons were also made by W. Gross (1971) between $L$. superbus on one hand and crossopterygians and actinopterygians on the other, on the basis of the study of the teeth. These comparisons led him to the conclusion that Lophosteus may be related to the struniiforms or the actinopterygians.

The cleithrum fragments described above have been compared with cleithra of Devonian crossopterygians, lungfishes, acanthodians and actinopterygians. Such an angulate cleithrum in only known in rhizodontid osteolepiforms (e. g., Eusthenopteron) and in some palaeonisciforms (e. g., Cheirolepis). The largest fragment is practically similar to its corresponding part in the cleithrum of Cheirolepis canadensis (Whiteaves) described by Lehman (1947, Fig. 16; Plate 7; see Fig. 2 in the present paper). The arrangement of the tubercles of the outer surface is also the same in both cases, but in Cheirolepis the tubercles are covered with enamel (ganoine), and the posterior part of the ventrolateral edge does not extend laterally as much as in $A$. hedei. The posterior limit of this bone, 


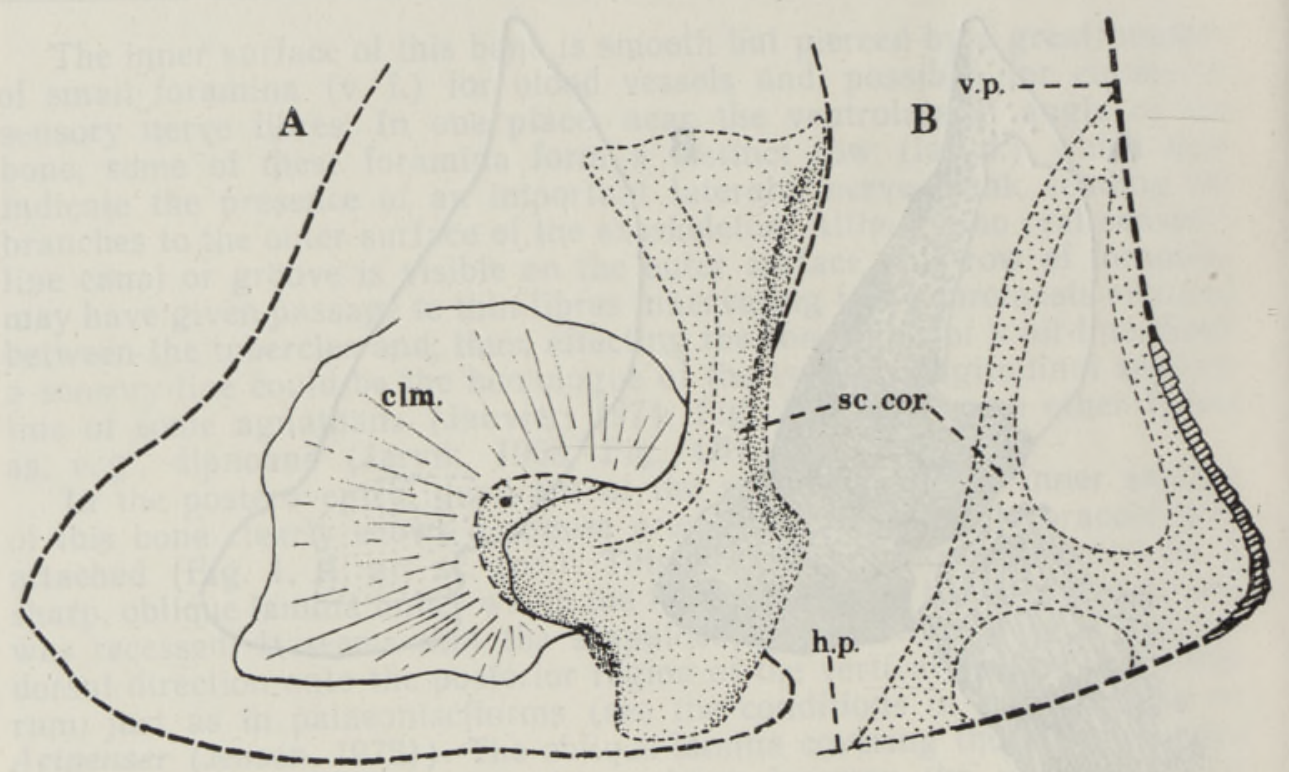

Fig. 3. Andreolepis hedei Gross. Cleithrum of the right side in medial (or slighly mediodorsal) view $(A)$ and in transverse section $(B)$. The hypothetic outlines of the scapulocoracoid (sc. cor.) dotted.

near the edge in question and dorsal to it, shows the same notch as in Cheirolepis and bends mesially in the same way to form a kind of gentle depression (d. p.).

The fragment, interpreted here as an anterior part of the cleithrum, shows on its anterodorsal edge a slight embayment which is also encountered in the corresponding part of the cleithrum of Cheirolepis.

The inner face of the cleithrum fragment of $A$. hedei shows some differences from that of Cheirolepis, especially in the position of the contact area for the scapulocoracoid. The position of the endoskeletal shoulder girdle on the cleithrum of Cheirolepis canadensis has been described by J. P. Lehman (1947, Fig. 10). It is situated much higher than in $A$. hedei, above the pectoral notch of the cleithrum, and does not extend forward as far as in the latter. The scapulocoracoid of $A$. hedei was lower and attached near the base of the vertical part of the cleithrum, a condition which is suggestive of the position of the arthrodiran scapulocoracoid on the thoracic armour. It may be supposed that the position of the scapulocoracoid in $A$. hedei fits better with the finfold theory in being more ventrolateral than lateral. The attempted reconstruction proposed here (Fig. 3) supposes that $A$. hedei possessed a scapulocoracoid of actinopterygian type (here inspired by the conditions in palaeonisciform, Jessen, 1972 ), but there is no certainty that the latter had developed dorsal and ventral buttresses.

The sharp ridge described by J. P. Lehman (1947) on the inner face of the cleithrum of Cheirolepis does not seem to be present in A. hedei, unless our specimen is broken behind it. This ridge may appear, in the phylogeny of the actinopterygians, consequently to the development of the reflected lamina, or postbranchial lamina, of the cleithrum. This lamina was probably absent on $A$. hedei, and the opercular bones may have covered the anterior part of the cleithrum directly. (Fig. 1, E, p. br. z). The conditions encountered in Cheirolepis are not very different; however, 


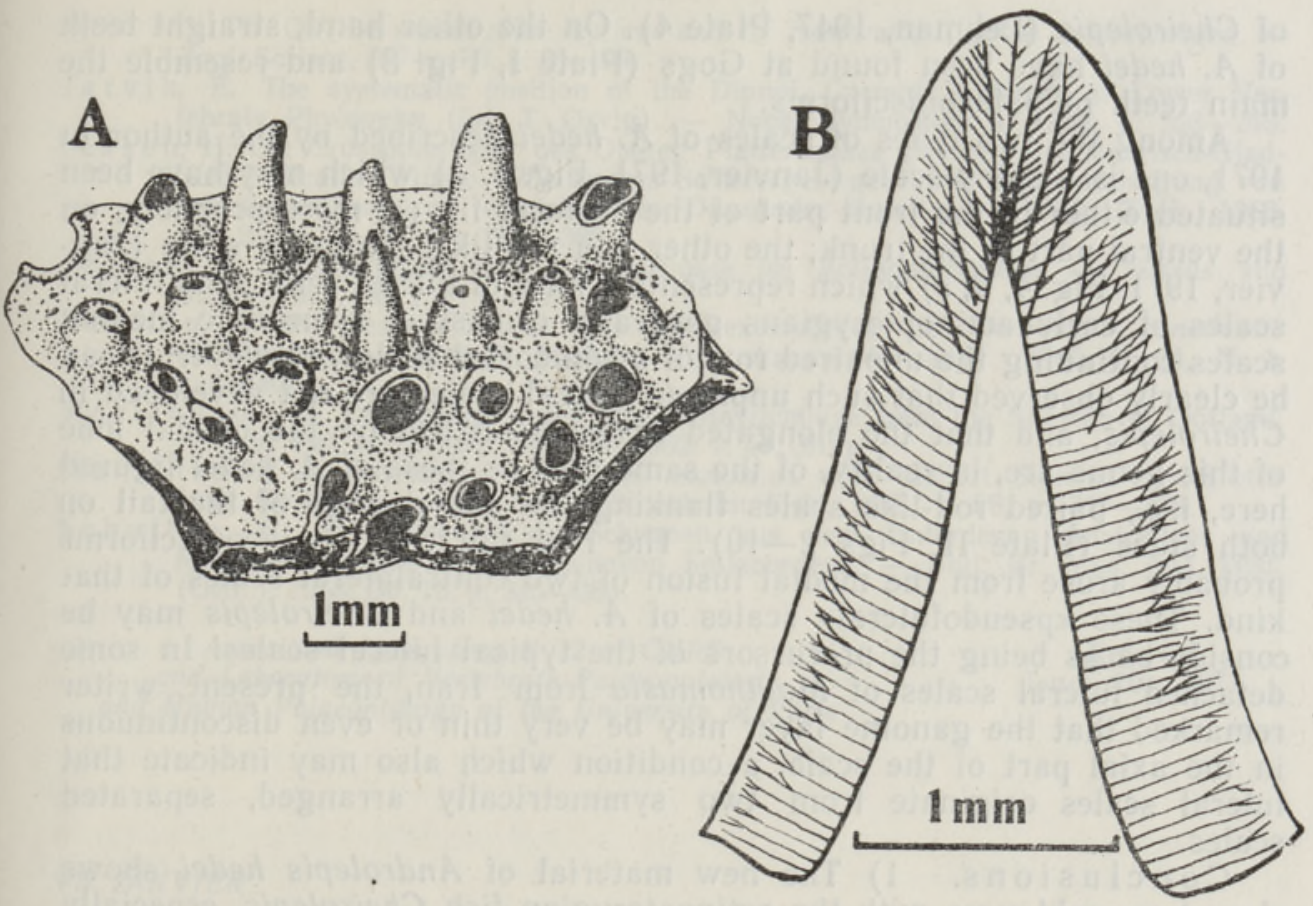

Fig. 4. Andreolepis hedei Gross. $A$ - Tooth-bearing plate (MNHN, Paris, GOT 8), Bvertical section through a detached tooth of the main tooth-row (combined drawing based on two thin sections).

the part of the cleithrum covered by the opercular bones is clearly bent in a medial direction and may represent a primitive postbranchial lamina. The ridge mentioned above is not present on the cleithrum of the choanate fishes (porolepiforms and osteolepiforms) which do not possess any welldeveloped postbranchial lamina either.

W. Gross (1971) wrote that he had the impression that Lophosteus superbus may be related to the crossopterygians and, more precisely, to the struniiforms, rather than to the actinopterygians. This assumption was based on the shape of the teeth, and on the resorption traces they present at their base. However, this author recognized that the teeth of L. superbus were devoid of enamel, like those of the actinopterygians. As far as $A$. hedei is concerned, the ornamentation of the dermal bones is somewhat suggestive of the spoon-shaped tubercles of Onychodus, but the shape of the cleithrum is very different from that of the struniiforms, which does not possess any horizontal part (Jessen, 1966). The oval tubercles covering the dermal bones of $A$. hede $i$ and tapering backwards are also suggestive of the shape of the scales of the same animal, and one may imagine that the passage from the cleithrum to the squamation of the flank was scarcely conspicuous in the living individuals. Furthermore, attention must be paid to the fact that the teeth of A. hedei (Fig. 4), like those of $L$. superbus, are devoid of enamel and are only made of dentine or, eventually, of some kind of durodentine at the tip. W. Gross (1971) stated that the main difference between the teeth of $L$. superbus and those of actinopterygians was the strong curvature of the former, opposed to the straightness of the latter. In reality, curved teeth can be observed in many primitive actinopterygians as, e. g., on the ectopterygoid 
of Cheirolepis (Lehman, 1947, Plate 4). On the other hand, straight teeth of $A$. hedei have been found at Gogs (Plate I, Fig. 8) and resemble the main teeth of palaeonisciforms.

Among the two types of scales of $A$. hedei described by the author in 1971 , one is a spiny scale (Janvier, 1971, Fig. 4, a) which may have been situated either in the front part of the pectoral fin or, more probably, on the ventral part of the trunk; the other is a rod-like, elongated scale (Janvier, 1971, Fig. $4, d, e$ ) which represents a kind of fulcral scale. The fulcral scales of early actinopterygians generally consist of symmetric median scales continuing the unpaired row of mediodorsal scales. However, it can be clearly observed that such unpaired fulcral scales are not developed in Cheirolepis, and that the elongated scales described on the caudal lobe of this genus are, in reality, of the same type as those of $A$. hedei figured here, i. e., paired rod-like scales flanking the dorsal edge of the tail on both sides (Plate II, Figs 2-10). The real fulcres of palaeonisciforms probably arose from the medial fusion of two contralateral scales of that kind. These «pseudofulcral» scales of $A$. hedei and Cheirolepis may be considered as being the precursors of the typical fulcral scales. In some detached fulcral scales of Moythomasia from Iran, the present writer remarked that the ganoine layer may be very thin or even discontinuous in the axial part of the scale, a condition which also may indicate that fulcral scales originate from two symmetrically arranged, separated scales.

Conclusions. 1) The new material of Androlepis hedei shows closest resemblances with the actinopterygian fish Cheirolepis, especially in the shape and ornamentation of the preserved part of the exoskeletal shoulder girdle. 2) The elongated scales of $A$. hedei are supposed to belong to the squamation of the dorsal part of the caudal lobe. They probably correspond to the fulcral scales of primitive actinopterygians and resemble very much the paired elongated scales flanking the edge of the tail in Cheirolepis. 3) The teeth of A. hedei are similar to those of Lophosteus superbus, in their shape and histological structure. They are devoid of enamel and show traces of resorption at their base. 4) A. hedei is of Lower Middle Ludlowian age and may represent the oldest known teleostome fish. The present writer agrees with W. Gross's statement that this fish is a representative of the class Actinopterygii but belongs to the order Lophosteiformes (Gross, 1969) which is characterized by, e. g., the absence of ganoine, and may have preceded the Palaeonisciformes in the evolution of this class. However, the hypothesis cannot be rejected that $A$. hedei, as well ds L. superbus, belongs to a hitherto unknown class of fishes which became extinct at the end of the Silurian and possessed some characters in common with the actinopterygians, the struniiformes and the acanthodians.

\section{REFERENCES}

Gross, W. Devonische Palaeonisciden-Reste in Mittel- und Osteuropa. - Paläont. Z., 1953 , Bd. 27, p. $85-112$.

Gross, W. Fragliche Actinopterygier-Schuppen aus dem Silur Gotlands. - Lethaia, 1968 , v. 1, p. $184-218$.

G ros s, W. Lophosteus superbus Pander, ein Teleostome aus dem Silur Oesels. - Lethaia, 1969 , v. 2 , p. $15-47$.

Gros s, W. Lophosteus superbus Pander: Zähne, Zahnknochen und besondere Schuppenformen. - Lethaia, 1971 , v. 4 , p. $131-152$.

$\mathrm{H}$ a m di. B., J a n vier, Ph. On some agnathan and actinopterygian remains firom the Emsian of Eastern Alborz (Iran). - Geol. Surv. Iran Reports (in press).

$\mathrm{J}$ a n vi er, Ph. Nouveau matériel d'Andreolepis hedei Gross, Actinopterygien énigmatique du Silurien de Gotland (Suède). - C. R. Acad. Sci. Paris, 1971, t. 273, p. $22123-2224$. 
$\mathrm{J}$ a nvier, Ph. On the sensory-line system and its innervation in the osteostracans Zool. Scripta, 1974 , v. 3, p. 91-99.

Jarvik, E. The systematic position of the Dipnoi. Current Problems of Lower Vertebrate Phylogeny (Ed. T. Ørvig). - Nobel Symposium 4, 1968, p. 223-245.

Jessen, H. Die Crossopterygier des Oberen Plattenkalkes (Devon) der Bergisch-Gladbach-Paffrather Mulde (Rheinisches Schiefergebirge) unter Berücksichtigung von amerikanischem und europäischem Onychodus-Material. - Ark. Zool., 1966, Ser. 2, Bd. $18, \mathrm{~N} 14$, p. $305-389$.

Jessen, H. Schultergürtel und Pectoralflosse bei Actinopterygiern. - Fossils and Strata, 1972, Bd. 1, p. 1-101.

Lehman, J. P. Description de quelques exemplaires de Cheirolepis canadensis (Whiteaves). - Kungl. Svenska Vetenskapsakad. handl., 1947, t. 24, N 4, p. $1-40$.

Martinsson, A. Ostracodes of the family Beyrichiidae from the Silurian of Gotland. - Publ. Pal. Inst. Univ. Uppsala, 1962, v. 41, 370 p.

Martinsson, A. Beyrichian ostracodes associated with earliest Silurian vertebrates from Gotland. - Geol. fören. Stockholm förh., 1966, v. 88, p. 327-339.

Schultze, H. P. Palaeonisciden-Schuppen aus dem Unterdevon Australiens und Kanadas und aus dem Mitteldevon Spitzbergens. - Bull. Br. Mus. Nat. Hist. (Geol.), 1968, Bd. 16, p. 343-368.

Associated Laboratory $\mathrm{N} 12$ of CNRS and Laboratory of Vertebrate Palaeonotology and Human Palaeontology of the University of Paris

\author{
Received \\ Jan., $\quad 20, \quad 1977$
}

Ph. JANVIER

\section{VANIM TUNTUD LUUKALA ANDREOLEPIS HEDEI GROSS (GOTLANDI SAARE LADLOU) NING LOFOSTEIIDIDE SUSTEMAATILINE KUULUVUS}

Gotlandi saarelt Gogsi leiukohast on kogutud keskladlou luukala Andreolepis hedei Gross määratavaid luid ja hambaid, millel on suur sarnasus kiiruimse Cheirolepis'e välisskeleti osadega. Leiud näivad kinnitavat W. Grossi oletust, et vanim teadaolev luukala ning ühtlasi üks vanimaid loútgsuuseid selgroogseid $A$. hedei kuulub tōenäoliselt kiiruimsete hulka.

\section{Ф. ЖAHBЬE}

\section{О ДРЕВНЕИШЕИ ТЕЛЕОСТОMЕ ANDREOLEPIS HEDEI GROSS (ЛУДЛОВ о. ГОТЛАНД) И О СИСТЕМАТИЧЕСКОМ ПОЛОЖЕНИИ ЛОФОСТЕИД}

Новый материал по древнейшей телеостоме Andreolepis hedei Gross (средний лудлов о-ва Готланд) показывает, что эта рыба наиболее близка к лучеперой Cheirolepis, в частности, по форме и орнаменту экзоскелетного плечевого пояса. Удлиненные чешуи A. hedei очень напоминают вытянутые в длину чешун возле края хвоста Cheirolepis. Eго зубы близки по форме и микроструктуре к зубам Lophosteus superbus Pander. Автор поддерживает мнение В. Гросса о том, что $A$. hedei является представителем класса Actinopterygii, но принадлежит к отряду Lophosteiformes, который предшествовал палеонискам. Он также согласен с тем, что A. hedei и L. superbus принадлежат к особой пруппе рыб, вымершей в конце силура, представители которой имеют общиє признаки с лучеперыми, струниформами и акантодами. 